ERIA Disc ussion Paper Series

\title{
Stability of Production Networks in East Asia: Duration and Survival of Trade*
}

\author{
Ayako OBASHI $^{\dagger}$ \\ Faculty of Economics, Keio University, Japan
}

September 2008

March 2009 (revised)

\begin{abstract}
This paper sheds light on the stability of international production networks in East Asia from the perspective of the duration and survival of bilateral trade relationships at the product-line level. Using highly disaggregated data for intra-East Asian machinery trade, survival analysis is conducted as well as the examinations of the duration and volatility of trade relationships. The product-level analyses reveal that, compared to machinery finished products, machinery parts \& components are traded through longer-lived and more stable relationships among East Asian countries. Once transactions are started, trade relationships of machinery parts \& components are more likely to be maintained between countries even at a long distance, regardless of the exchange-rate fluctuations. The probability of discontinuing trade relationships of machinery finished products, on the other hand, are more likely to be sensitive to the level of trading cost as well as the exchange-rate fluctuations.
\end{abstract}

Keywords: Duration of trade; survival analysis; fragmentation; East Asia.

JEL Categories: F10; F14.

\footnotetext{
* The author would like to thank Professor Fukunari Kimura for helpful comments. The author also would like to thank participants in the 11th International Convention of the East Asian Economic Association (EAEA) held in Manila, the Philippines in November 2008 and those in the "Globalisation, Growth and Development in Asia" Conference organized by the University of Nottingham Malaysia Campus in January 2009 for constructive comments and suggestions.

${ }^{\dagger}$ Ayako Obashi. Faculty of Economics, Keio University, 2-15-45 Mita, Minato-ku, Tokyo 108-8345, Japan. Phone: +81-3-3453-4511. E-mail: aobashi@gs.econ.keio.ac.jp.
} 


\section{Introduction}

The development of international production and distribution networks in East Asia has stimulated a number of studies on its nature and characteristics as well as discussions on policy implications of its existence. While most of empirical works use aggregate international trade data, as a result, they overlook the underlying dynamics of trade. Among a number of interesting economic phenomena behind the aggregate trade value, this paper investigates the duration and survival of bilateral trade relationships at the product-line level so as to clarify the stability of production networks stretched across the region.

The production networks are formed by a firm's decision on whether or not to split up a previously integrated production process into two or more components and where to locate fragmented production blocks. Jones and Kierzkowski (1990), the seminal work on the fragmentation theory, suggested how integrated production processes could be characterized by a series of production blocks which are connected by service links such as transportation, communication and coordination. ${ }^{1}$ Specifically, fragmentation becomes optimal when the costs of service links is low enough as well as when production cost per se is significantly reduced by taking advantage of differences in technologies and factor prices among locations. In terms of production networks in East Asia, considering its sophistication in the combination of intra-firm and arm's-length transactions, Kimura and Ando (2005) claim that the concept of fragmentation must be expanded to two dimensions including not only geographic distance but also the boundary of the firm. The idea of transaction costs emerging from disintegration of a firm has been long discussed in the industrial organization literature of vertical integration, and it has recently been incorporated into international trade models (See, for example, Grossman and Helpman, 2002, 2004, 2005).

The form of transactions of intermediate goods in international production networks is distinctly different from transactions of only finished products made entirely in one country. First, those transactions are within the networks created, coordinated, and managed by multinational enterprises across borders. All the parts \&

\footnotetext{
${ }^{1}$ For the fragmentation theory, see Arndt and Kierkowski (2001) and Deadorff (2001).
} 
components produced within the network are essential to manufacturing a particular product, and each of the fragmented production blocks is often not be able to function effectively without coordination between upstream and downstream production processes. Second, to connect remotely-located production blocks from upstream to downstream production processes, service link costs including transport costs, telecommunication costs, and coordination costs are required. Service link typically has strong economies of scale in both static and dynamic sense. From the dynamic standpoint, service link plays a critical role in a firm's decision on whether or not to set up the network with sunk costs to invest in a newly fragmented production block. These two features of the transactions of intermediate goods in international production networks lead to a relation-specific nature of the transactions. Due to such relation-specific nature, once a trade relationship is established, it would appear that the transaction of intermediate goods in international production networks is more long-lasting compared to the other transactions.

Since the beginning of the 1990s, East Asian countries have expanded and deepened intra-regional trade relationships, particularly in machinery parts \& components trade. The intra East Asian export value of machinery parts \& components rapidly increased 4.3 fold, while the overall intra-regional export value expanded by a factor of 2.6 in real terms from 1993 to 2006. The diversity of the East Asian region promotes opportunities for multinationals to locate fragmented production blocks in different locations with different location advantages all over the region. Although the formation of international production networks has not been limited to the machinery sector, the machinery industry is by far the most important, both quantitatively and qualitatively, and extends the most sophisticated networks across East Asia and other regions (See Fukao et al. 2003; Athukorala and Yamashita 2006; Kimura 2006). In 2006, the share of machinery parts \& components in the total intra-regional merchandise exports from and imports to respective East Asian countries ranges from $13 \%$ to $66 \%$ and $14 \%$ to $52 \%$, respectively.

The goal of this paper is to detect differences in stability between the transactions of intermediate goods in international production networks and the other transactions in East Asia. To this end, survival analysis is conducted, as well as the examinations of the duration and volatility of trade relationships. In the light of the unprecedented 
development of international production networks in machinery industries with the explosive expansion of intra-regional machinery parts \& components trade in East Asia over the last couple of decades, this paper specifically compares intra-regional machinery trade of parts \& components with that of finished products. The country-product level data enables us to reveal how long a bilateral trade relationship at the product-line level is continued without interruption once the transaction is started and how the duration of trade relationships differs between machinery parts \& components and finished products.

The novel empirical approach highlights unexplored facts of international trade and confirms the difference in the probability of the survival of trade relationships between parts \& components and finished products in intra-East Asian machinery trade. First and foremost, compared to finished products, machinery parts \& components are traded through longer-lived relationships among East Asian countries. Second, trade relationships of parts \& components are more likely to be maintained between countries even at a long distance, regardless of the exchange-rate fluctuations. The probability of discontinuing trade relationships of finished products, on the other hand, are more likely to be sensitive to the level of trading cost as well as the exchange-rate fluctuations. Furthermore, empirical results provide intriguing clues to facilitate the development of more stable trade relationships all over the region.

This paper offers a new insight to accumulated studies on intra-regional trade and production networks in East Asia. It also contributes to a pioneering work on duration of trade by Besedeš and Prusa (2006a; 2006b). Despite an emerging body of literature on trade at the country-product level, the duration of trade has not received much attention until very recently. Besedeš and Prusa (2006a), who first investigated the duration of the US imports, find the country-product-level trade to be surprisingly volatile with the median duration of four year. As their companion paper, Besedeš and Prusa (2006b) highlight that differentiated products have a longer median duration and a higher probability of survival than homogeneous products, based on a search cost model of international trade. Besedeš (2008) provides additional facts on the survival of the US imports from a search cost perspective. The prevalence of short-lived trade relationships has been also found in just a few studies including Nitch (2007) for German imports and Blyde (2008) for the exports from Latin American countries. 
The rest of this paper proceeds as follows: the next section outlines the duration and volatility of trade relationships in intra-East Asian machinery trade. Focusing on the difference between machinery parts \& components and finished products, the survival analysis is performed in two steps. As a first step, Section 3 examines the probability of the survival of trade relationships, employing the Kaplan-Meier method. As a second step, Section 4 examines the interplay of factors that may affect the duration of trade, employing the Cox proportional hazard model. Section 5 discusses the interpretation of the empirical results. And the last section concludes.

\section{The Duration and Volatility of Trade Relationships in Intra-East Asian Machinery Trade}

To examine trade relationships in intra-East Asian machinery trade, this paper uses bilateral import data at the six-digit level of Harmonized System (HS) 1992 from 1993 to 2006 obtained from the United Nations Commodity Trade Statistics Database (UN Comtrade). ${ }^{2}$ The HS six-digit level is the most detailed disaggregated level of trade data that is internationally comparable and publically available. There exist 1,124 product lines at the six-digit level of HS 1992 just for machinery industry and 5,040 product lines for all industries.

This paper focuses on bilateral trade relationships among nine East Asian countries, namely China, Hong Kong, Indonesia, Japan, Malaysia, the Philippines, Rep. of Korea, Singapore, and Thailand. The machinery industry of interest includes general machinery (HS84), electric machinery (HS85), transport equipment (HS86-89), and precision machinery (HS90-92). The HS classification codes are grouped into parts \& components and finished products, following Ando and Kimura (2005). 1,124 product lines of machinery industry consist of 436 parts \& components and 688 finished products.

For each exporter-importer-product pair, we can identify whether a trade relationship is active in a given year and how long a trade relationship is continued

\footnotetext{
${ }^{2}$ See Appendix A for the details of trade data used throughout this paper.
} 
without interruption. Table 1 reports the basic statistics for the number of years in which a trade relationship is active during 1993-2006 (14 years) for intra-East Asian machinery trade: mean, median, cumulative percentages by the number of years active. The size of observations for all the machinery products is 79,804 , which equals 1,124 product lines multiplied by 71 pairs. $^{3}$ The figures are compared between parts \& components and finished products.

Table 1. Number of Years Active during 1993-2006 for Exporter-importer-product Pairs

\begin{tabular}{|c|c|c|c|c|c|c|c|}
\hline \multirow[t]{2}{*}{ Product type } & \multirow[t]{2}{*}{ Mean } & \multicolumn{6}{|c|}{ Cumulative percentages (\%) } \\
\hline & & & 0 & 1 & 7 & 13 & \\
\hline $\mathrm{P} \& \mathrm{C}$ & 9.2 & 12 & 10.2 & 15.5 & 34.7 & 60.5 & 30,956 \\
\hline FP & 6.7 & 6 & 20.2 & 29.5 & 55.7 & 78.8 & 48,848 \\
\hline All machinery products & 7.7 & 8 & 16.3 & 24.1 & 47.6 & 71.7 & 79,804 \\
\hline
\end{tabular}

The trade relationships of parts \& components are more active than those of finished products during the period. For all the potential exporter-importer-product pairs including those inactive throughout the period, the mean number of years active is 9.2 for parts \& components and 6.7 for finished products. This result can be interpreted as a reflection of the difference in the duration and volatility of trade relationships. Our interest is then turned towards the length of time a particular product is continuously traded between an exporter-importer pair. For instance, if country $i$ started to export product $h$ to country $j$ in 1994 and ceased to export the product in 1998, the trade relationship is regarded as having a spell length of four. As some of trade relationships were broken off and restored after a certain period, at least a year, which is referred to as multiple spells, the number of spells by exporter-importer-product pair as well as their lengths should be examined.

Tables 2 and 3 report the basic statistics for the number and length of spells, focusing on exporter-importer-product pairs active at least one year during 1993-2006. As multiple spells are treated as independent, the size of observations in Table 3 is larger than that in Table 2. It would be better to treat multiple spells accompanied by a certain period of interruption as independent because separated spells of an

\footnotetext{
${ }^{3}$ Note that data for Singapore's imports from Indonesia, which only have been officially reported since 2003, are not included in the sample used in this and the following sections.
} 
exporter-importer-product pair are highly likely to involve different firms of exporter and importer countries.

Table 2. Number of Spells for Exporter-importer-product Pairs

\begin{tabular}{|c|c|c|c|c|c|c|c|}
\hline \multirow{3}{*}{ Product type } & \multirow{3}{*}{ Mean } & \multicolumn{6}{|c|}{ Cumulative percentages (\%) } \\
\hline & & \multirow[t]{2}{*}{ Median } & \multicolumn{4}{|c|}{ by number of spells } & \multirow[t]{2}{*}{ Obs. } \\
\hline & & & 1 & 2 & 3 & 4 & \\
\hline P\&C & 1.7 & 1 & 59.2 & 80.3 & 93.5 & 98.8 & 27,808 \\
\hline FP & 1.9 & 2 & 47.0 & 72.9 & 90.3 & 97.8 & 39,005 \\
\hline All machinery products & 1.8 & 1 & 52.1 & 76.0 & 91.6 & 98.2 & 66,813 \\
\hline
\end{tabular}

Table 3. Length of Spells for Bilateral Trade Relationships at the Product-line Level

\begin{tabular}{|c|c|c|c|c|c|c|c|c|}
\hline \multirow{3}{*}{ Product type } & \multirow{3}{*}{ Mean } & \multicolumn{7}{|c|}{ Cumulative percentages (\%) } \\
\hline & & \multirow[t]{2}{*}{ Median } & \multicolumn{5}{|c|}{ by length of spells } & \multirow[t]{2}{*}{ Obs. } \\
\hline & & & 1 & 2 & 4 & 7 & 10 & \\
\hline P\&C & 6.1 & 3 & 32.0 & 44.2 & 55.5 & 64.4 & 69.3 & 46,823 \\
\hline $\mathrm{FP}$ & 4.3 & 2 & 42.9 & 57.2 & 69.2 & 79.6 & 83.4 & 74,937 \\
\hline All machinery products & 5.0 & 2 & 38.7 & 52.2 & 63.9 & 73.8 & 78.0 & 121,760 \\
\hline
\end{tabular}

Even with aggregated trade data at the country level rather than data on the firm-level export activities, the break and restoration of trade relationships occur at significant frequency particularly for finished products. The mean number of spells is 1.7 for machinery parts \& components and 1.9 for finished products. For parts \& components, the median number of spells is one, meaning a single spell, but still $41 \%$ of exporter-importer-product pairs experience multiple spells. For finished products, $53 \%$ of exporter-importer-product pairs experience multiple spells, about a half of which, $27 \%$ experience more than two spells. In addition, short-lived trade relationships are more prevalent than expected particularly for finished products. The median (mean) length of spells is three (6.1) years for parts \& components and two (4.3) years for finished products.

\section{The Survival of Trade Relationships}

The descriptive analyses in the last section suggest that, compared to finished 
products, machinery parts \& components are likely to be traded through more stable relationships without interruption for a longer period of time. Stimulated by these facts, this and the next sections perform the survival analysis in two steps, highlighting the difference in the probability of the survival of trade relationships between parts \& components and finished products in intra-East Asian machinery trade. As a first step, this section examines the probability of the survival of trade relationships, employing the Kaplan-Meier method. As a second step, the next section examines the interplay of country-specific and pair-specific characteristics that may affect the duration of trade, employing the Cox proportional hazard model.

\subsection{Kaplan-Meier Estimates}

Estimated Kaplan-Meier survival rates for bilateral trade relationships at the product-line level in intra-East Asian machinery trade are reported in Table 4 and the corresponding survival curves are graphed in Figure $1 .^{4}$ Our interest here is the duration of trade, or specifically, the probability that a particular product will continue to be traded between an exporter-importer pair in the $t$-th year given that it has been traded until the previous year. Estimates are compared between parts \& components and finished products.

Table 4. Estimated Kaplan-Meier Survival Rates for Bilateral Trade Relationships at the Product-line Level: By Different Samples

\begin{tabular}{lllccccc}
\hline \multirow{2}{*}{ Sample } & Product & \multicolumn{5}{c}{ Estimated K-M survival rate } & Number of \\
\cline { 2 - 6 } & type & $1^{\text {st }}$ year & $2^{\text {nd }}$ year & $4^{\text {th }}$ year & $7^{\text {th }}$ year & $10^{\text {th }}$ year & spells \\
\hline All spells & P\&C & 0.72 & 0.61 & 0.52 & 0.47 & 0.45 & 46,823 \\
& FP & 0.62 & 0.50 & 0.39 & 0.32 & 0.29 & 74,937 \\
Without 1993-origin spells & P\&C & 0.61 & 0.47 & 0.35 & 0.29 & 0.27 & 29,264 \\
& FP & 0.54 & 0.38 & 0.26 & 0.20 & 0.18 & 54,260 \\
1-year-gap-adjusted & P\&C & 0.71 & 0.61 & 0.53 & 0.49 & 0.48 & 44,966 \\
& FP & 0.61 & 0.48 & 0.39 & 0.34 & 0.32 & 71,822 \\
The first spells only & P\&C & 0.75 & 0.66 & 0.59 & 0.54 & 0.52 & 27,808 \\
& FP & 0.64 & 0.53 & 0.44 & 0.35 & 0.33 & 39,005 \\
Single spells only & P\&C & 0.91 & 0.90 & 0.88 & 0.88 & 0.87 & 16,458 \\
& FP & 0.78 & 0.74 & 0.71 & 0.70 & 0.70 & 18,338 \\
\hline
\end{tabular}

Note: The difference of survival function by product type for each sample is significant at the $1 \%$ level using the log-rank test.

\footnotetext{
${ }^{4}$ The survival function is estimated nonparametrically using the Kaplan-Meier product limit estimator, along the lines of Besedeš and Prusa (2006a) and other previous studies.
} 
Figure 1: Kaplan-Meier Estimates of Survival Curves for Bilateral Trade Relationships at the Product-line Level: by Different Samples
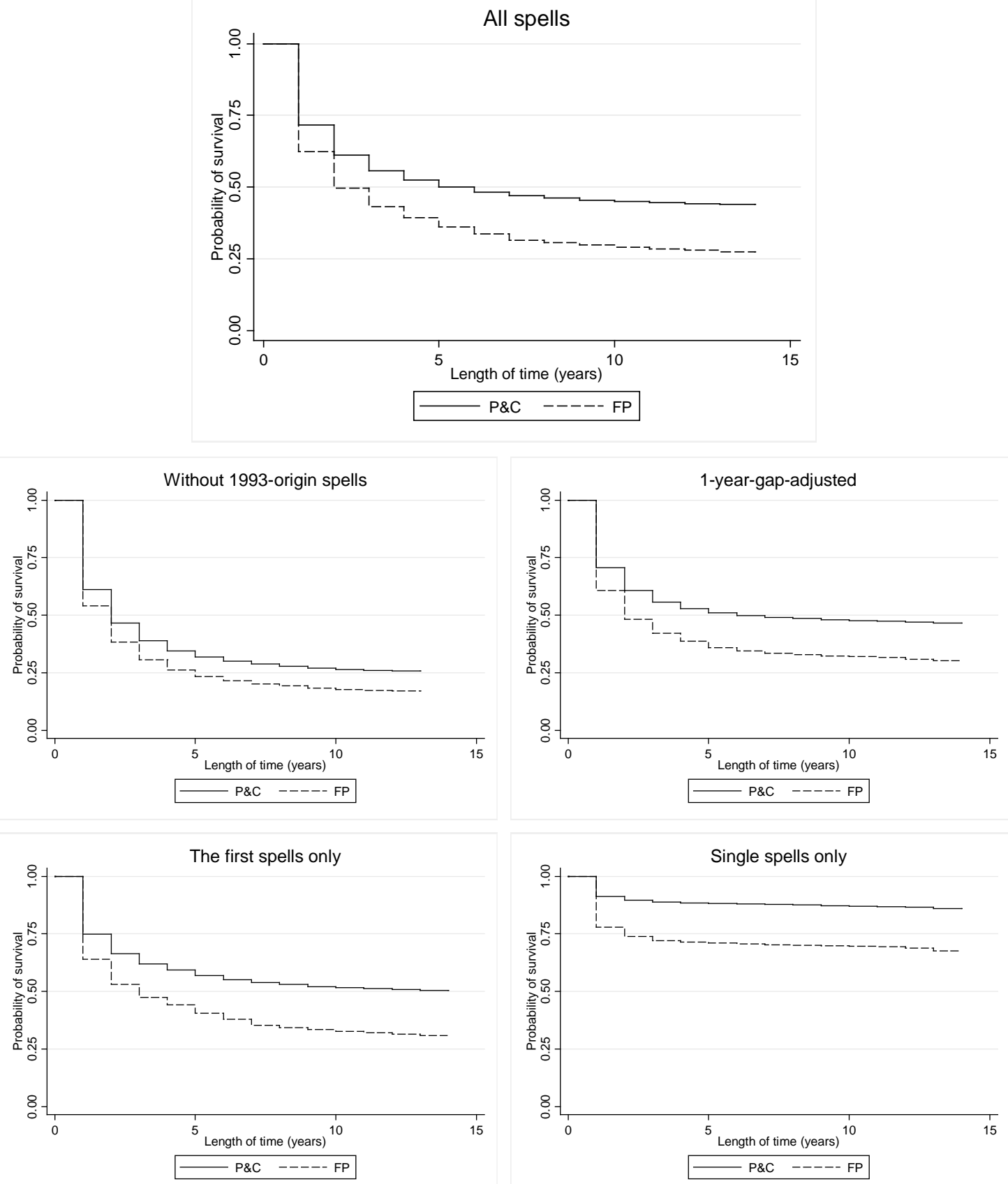

Note: The difference of survival function by product type for each sample is significant at the $1 \%$ level using the log-rank test.

The result for all the observed spells during 1993-2006 is reported in the first two rows in the table and shown in the top panel of the figure. The shape of estimated survival curves for parts \& components and finished products look similar. Both 
survival curves are downward sloping with a decreasing slope. The conditional probability of discontinuance, i.e., hazard rate, is quite high in the early years, but then sharply decreases once a trade relationship lasts for a certain period of time: a kind of threshold effect is observed. A substantial portion of trade relationships fail within the first four years, especially in the first year when the hazard rates are $28 \%$ and $38 \%$ for parts \& components and finished products, respectively. For the later years, on the other hand, survival rates slowly decline by only $5-7 \%$ between the fourth and seventh years, and remain nearly constant afterwards. There is little additional probability of discontinuance beyond the seventh year because most of the long-lasting spells ended in 2006, the end year of the sample, and are classified as censored rather than failures.

Although the survival curves are similar in shapes, survival rates are higher for parts \& components than finished products at any point of time, and the gap between them is gradually widening. The difference of survival function between parts \& components and finished products is statistically significant using the log-rank test. One half of trade relationships of finished products fail during the first two years, whereas, for parts \& components, $40 \%$ fail during the first two years and the median survival time is five years. As a related finding, the survival curve becomes nearly flat at the earlier point of time for parts \& components. The threshold duration for a longer survival appears to be shorter for parts \& components than finished products.

\subsection{Robustness Check}

Two kinds of exercises are performed. First, to address the left-censoring issue, survival functions are re-estimated for the sample without spells which begun in 1993. As the beginning year of the data used in this paper is 1993, there is no information on whether trade relationships begun exactly in 1993 or in some prior year. ${ }^{5}$ Second, regarding possibly incorrectly recorded multiple spells due to measurement error, survival functions are estimated using the modified sample. As pointed out by Besedeš and Prusa (2006a; 2006b), if the interruption time between spells is quite short, the gap is suspected to be incorrectly recorded and it may be more appropriate to regard

\footnotetext{
${ }^{5}$ Similarly, for the end year of data, trade relationships may have failed exactly in 2006 or may be persistent afterwards. Since Kaplan-Meier survival rates are estimated using information of not only observed failures but also right-censored observations, it must be appropriate to interpret the length of right-censored spells as a minimum.
} 
the two spells before and after the gap as a single longer spell. The length and number of spells are adjusted by assuming that a one-year gap between spells which last at least two years is a result of a recording error. ${ }^{6}$ Also, a one-year gap may be partly due to a discrete nature of trade data which is compiled on an annual basis.

Although estimated survival rates vary among different samples, it is striking that the aforementioned two features of the survival functions are robust (see Table 4 and Figure 1 again). For further reference, survival functions are estimated only for the first spells of respective exporter-importer-product pairs and for single spells, and the two features still hold.

\section{The Factors behind the Survival of Trade Relationships}

In order to control for country-specific and pair-specific characteristics that may influence the duration of trade, the Cox proportional hazards model is estimated. As well as confirming the difference in the probability of the survival of trade relationships between machinery parts \& components and finished products, this section examines how covariates affect the hazard rate.

\subsection{Semi-parametric Cox Proportional Hazards Model}

The semi-parametric Cox proportional hazards model asserts that the hazard rate for the $m$-th subject in the sample is

$$
h\left(t \mid x_{\boldsymbol{m}}\right)=h_{0}(t) \exp \left(\boldsymbol{x}_{\boldsymbol{m}} \beta\right),
$$

where $\boldsymbol{x}_{\boldsymbol{m}}$ denotes a vector of $\boldsymbol{m}$-th subject's covariates and coefficients $\beta$ are to be estimated. ${ }^{7}$ The Cox model is by far the most popular of choices in the analysis of survival data. A particular advantage of the model is that the baseline hazard function,

\footnotetext{
${ }^{6}$ Although I considered alternative criteria to adjust possibly incorrectly recorded one-year gaps, results did not change qualitatively.

${ }^{7}$ As the Cox model is a continuous model while the survival data used in this paper is on an annual basis, in which some failures occur at the same survival time (year), the Breslow (1974)'s approximation is assumed so as to treat tied failures.
} 
$h_{0}(t)$, is left unspecified and not estimated. What is assumed is that the covariates multiplicatively shift the baseline hazard which is common to all the subjects. In this regard, however, estimation is to be stratified by machinery subsector, namely general machinery, electric machinery, transport equipment, and precision machinery, allowing the baseline hazard to vary among strata.

The hazard rate for individual subject equals to the baseline hazard when the value of all covariates is set to zero. Exponentiated respective coefficients are then interpreted as the ratio of the hazard rates, which is referred to as hazard ratio, for a one-unit change in the corresponding covariate. Hazard ratio is greater than one if the corresponding covariate negatively affects the duration of trade relationships, and vice versa. A ratio equal to one implies no impact on the duration of trade relationships.

Firstly, to confirm the different possibilities of the survival of trade relationships between machinery parts \& components and finished products, the Cox model is estimated simply using time-invariant covariates as well as control variables. Distance and dummy variables for common official language and common border are included, since, in the gravity literature, it is well known that countries at smaller distance and sharing a common language and a common border tend to trade more with each other. ${ }^{8}$ Those variables might also affect the duration of trade relationships through pushing up or lowering the cost of trading. To control for the initial size of transaction, the logarithm of trade value in the first year is included. ${ }^{9} \quad$ A trade relationship started with a smaller trade value at the country level, which is probably economically less important for either or both of exporter and importer countries in the beginning, may face a greater risk of discontinuance. Instead of applying the cutoff value to trade data, the initial trade value is taken into consideration.

Regarding the prevalence of multiple spells, two control variables are included. One is a dummy variable for subsequent spells, following Besedeš and Prusa (2006b). The experience of discontinuing trade relationships may lead another failure; on the other hand, a trade relationship restarted after a certain period of no trade may not fail again, owing to accumulated information about the trade counterpart at the country level.

\footnotetext{
${ }^{8}$ See Appendix B for the data sources of covariates.

9 Trade data are deflated by the wholesale price index (WPI) in the U.S. to obtain a constant dollar series.
} 
In either case, the probability of the survival will depend on the experience of failure though multiple spells are treated as independent because separated spells would involve different firms.

The other is a dummy variable for exporter-importer-product pairs for which breaks and restoration of trade relationships are observed very frequently. As is clear from Table 2, about 8\%, a non-negligible portion of exporter-importer-product pairs have four or more spells, meaning that they experienced breaks accompanied by restoration three times or more in just 14 years. Looking into HS six-digit codes of those exporter-importer-product pairs, there seems to be product-specific factor behind the extraordinary experiences, as well as country-specific and pair-specific factors. Some product lines such as equipment and facilities might not necessarily be traded bilaterally every year even at the country level. ${ }^{10}$ Or, some product lines might be more likely to be unintentionally misclassified as a different product-line due to unfamiliarity with the product or as a different country of origin due to entrepôt trade (See Yeats, 1995). A dummy variable which takes a value of one if an exporter-importer-product pair in question have four or more spells during the period and zero otherwise is then included.

Next, the survival data are split at every observed failure time, i.e., at every year, for respective spells, which enables us to estimate the Cox model using time-dependent covariates as well as time-invariant variables. As for country-year-specific characteristics, exporter country's GDP and importer country's GDP are included as standard gravity variables of economic size. ${ }^{11}$ Supplier firms located in larger economies might be able to maintain a longer trade relationship due to larger production capacities. Meanwhile, a larger pool of potential buyers might ease accommodating demand fluctuation through switching buyers within a country, leading to a longer trade relationship at the country level.

\footnotetext{
${ }^{10}$ For instance, in the multiple spells sample, machines for extruding, drawing, texturing or cutting man-made textile materials (HS844400) and machinery for the extraction or preparation of animal or fixed vegetable fats or oils (HS847920) are observed at most significant frequency. For those products, about one fourth of exporter-importer pairs have experienced stops and restarts of trade three times or more in just 14 years.

${ }^{11}$ We would prefer value added of machinery industry of its own (ideally, disaggregated by product type) to GDP as a variable indicating the size of economic activities of machinery industry. Due to lack of data publicly available, we have no alternative but to employ GDP.
} 
The firm's ability to maintain trade relationships might also be affected by the competitiveness environment in an exporter country, which is assumed to be related to the institutional framework, as well as institutional stability in an importer country. To capture institutional quality for both exporter and importer countries, country credit rating indicators compiled by Institutional Investor are included. The credit ratings are based on evaluations of the country's creditworthiness, provided by economists and international banks. The numerical ratings range from 0 to 100 , with 100 corresponding to the lowest chance of sovereign default on the country's foreign currency debts.

The probability of the survival of trade relationships will depend not only on exporter-importer-product-pair-specific experience, which is captured by the subsequent spells dummy, but also on importer country's experience of purchasing a particular product from abroad. The cumulative number of supplier countries, which is counted for respective importer-product pairs excluding an exporter country in question itself, is then included. A trade relationship which is commenced under a competitive market environment with a large number of potential suppliers for a particular product might be more likely to be lasting.

As for pair-year-specific characteristics, the absolute value of the difference in per capita GDP between exporter and importer countries is included as a proxy for wage differential, which may reflect different factor intensity, or production technology, and factor endowment. These differences in production conditions are presumed to encourage cross-border production sharing, leading to a longer-lasting trade relationship.

To capture supplier firm's competitiveness in terms of relative trading cost, the year-on-year percentage change in real exchange rate (RER) for exporter country's currency to importer country's currency is included. ${ }^{12}$ An increase in RER reflects that an exporter country's currency has weakened relative to importer country's currency with consideration to inflation in respective economies. If an exporter country's currency depreciates, since its supplier firms will become more competitive relative to

\footnotetext{
12 The annual average of nominal exchange rate is deflated by WPI for each country. As for China and the Philippines, which have not reported WPI during the period, the consumer price index is used instead of WPI as a deflator.
} 
those located in the export counterpart, the suppliers might be less likely to exit from the market.

\subsection{Cox Hazards Estimates}

Table 5 provides the Cox proportional hazards estimates for bilateral trade relationships at the product-line level in intra-East Asian machinery trade during 1993-2006, using time-invariant covariates. Besides the aforementioned control variables, exporter and importer country fixed effects are included to control for unobserved country-specific characteristics. The sample and the trade relationships of interest are listed at the top of each column, and the covariates and control variables are in the first left column of the table. Units in which respective variables are measured are in parentheses. $^{13}$ Estimated coefficients are expressed in terms of hazard ratios.

Table 5. Cox Proportional Hazards Estimates for Bilateral Trade Relationships at the Product-line Level: Time-invariant Covariates Only

\begin{tabular}{|c|c|c|c|c|c|c|c|c|c|}
\hline & \multicolumn{3}{|c|}{ All spells } & \multicolumn{3}{|c|}{$\begin{array}{c}\text { Without } \\
\text { 1993-origin spells }\end{array}$} & \multicolumn{3}{|c|}{ 1-year-gap-adjusted } \\
\hline & $\begin{array}{l}\text { All machinery } \\
\text { products }\end{array}$ & $\mathrm{P} \& \mathrm{C}$ & FP & $\begin{array}{l}\text { All machinery } \\
\text { products }\end{array}$ & $\mathrm{P} \& \mathrm{C}$ & FP & $\begin{array}{l}\text { All machinery } \\
\text { products }\end{array}$ & $\mathrm{P} \& \mathrm{C}$ & FP \\
\hline Distance $(1,000 \mathrm{~km})$ & $\begin{array}{c}1.054^{* *} \\
(0.000)\end{array}$ & $\begin{array}{l}1.047 * * \\
(0.000)\end{array}$ & $\begin{array}{c}1.059 * * \\
(0.000)\end{array}$ & $\begin{array}{c}1.036 * * \\
(0.000)\end{array}$ & $\begin{array}{l}1.028 * * \\
(0.000)\end{array}$ & $\begin{array}{l}1.040 * * \\
(0.000)\end{array}$ & $\begin{array}{c}1.055^{* *} \\
(0.000)\end{array}$ & $\begin{array}{l}1.048 * * \\
(0.000)\end{array}$ & $\begin{array}{l}1.060 * * \\
(0.000)\end{array}$ \\
\hline Border dummy & $\begin{array}{c}0.999 \\
(0.964)\end{array}$ & $\begin{array}{c}1.011 \\
(0.707)\end{array}$ & $\begin{array}{c}0.997 \\
(0.866)\end{array}$ & $\begin{array}{c}0.981 \\
(0.323)\end{array}$ & $\begin{array}{c}0.978 \\
(0.544)\end{array}$ & $\begin{array}{c}0.980 \\
(0.381)\end{array}$ & $\begin{array}{c}1.002 \\
(0.891)\end{array}$ & $\begin{array}{l}1.016 \\
(0.627)\end{array}$ & $\begin{array}{c}1.000 \\
(0.983)\end{array}$ \\
\hline Language dummy & $\begin{array}{c}0.901 * * \\
(0.000)\end{array}$ & $\begin{array}{c}0.909 * * \\
(0.000)\end{array}$ & $\begin{array}{c}0.893 * * \\
(0.000)\end{array}$ & $\begin{array}{c}0.947 * * \\
(0.000)\end{array}$ & $\begin{array}{c}0.965 \\
(0.187)\end{array}$ & $\begin{array}{c}0.935^{* *} \\
(0.000)\end{array}$ & $\begin{array}{c}0.902 * * \\
(0.000)\end{array}$ & $\begin{array}{c}0.914 * * \\
(0.000)\end{array}$ & $\begin{array}{c}0.893 * * \\
(0.000)\end{array}$ \\
\hline Log of initial trade value (US\$) & $\begin{array}{c}0.842 * * \\
(0.000)\end{array}$ & $\begin{array}{c}0.807 * * \\
(0.000)\end{array}$ & $\begin{array}{c}0.858 * * \\
(0.000)\end{array}$ & $\begin{array}{c}0.913 * * \\
(0.000)\end{array}$ & $\begin{array}{l}0.903 * * \\
(0.000)\end{array}$ & $\begin{array}{c}0.915 * * \\
(0.000)\end{array}$ & $\begin{array}{c}0.846 * * \\
(0.000)\end{array}$ & $\begin{array}{c}0.813^{* *} \\
(0.000)\end{array}$ & $\begin{array}{c}0.861^{* *} \\
(0.000)\end{array}$ \\
\hline Subsequent spells dummy & $\begin{array}{c}0.680^{* *} \\
(0.000)\end{array}$ & $\begin{array}{c}0.629 * * \\
(0.000)\end{array}$ & $\begin{array}{c}0.702 * * \\
(0.000)\end{array}$ & $\begin{array}{c}0.624^{* *} \\
(0.000)\end{array}$ & $\begin{array}{c}0.577 * * \\
(0.000)\end{array}$ & $\begin{array}{c}0.648 * * \\
(0.000)\end{array}$ & $\begin{array}{c}0.785^{* *} \\
(0.000)\end{array}$ & $\begin{array}{c}0.725 * * \\
(0.000)\end{array}$ & $\begin{array}{c}0.814 * * \\
(0.000)\end{array}$ \\
\hline Frequent breaks dummy & $\begin{array}{c}2.669 * * \\
(0.000)\end{array}$ & $\begin{array}{c}3.341 * * \\
(0.000)\end{array}$ & $\begin{array}{c}2.375^{* *} \\
(0.000)\end{array}$ & $\begin{array}{c}1.890 * * \\
(0.000)\end{array}$ & $\begin{array}{l}2.276 * * \\
(0.000)\end{array}$ & $\begin{array}{c}1.726 * * \\
(0.000)\end{array}$ & $\begin{array}{c}2.680 * * \\
(0.000)\end{array}$ & $\begin{array}{c}3.494^{* *} \\
(0.000)\end{array}$ & $\begin{array}{c}2.336 * * \\
(0.000)\end{array}$ \\
\hline P\&C dummy & $\begin{array}{c}0.684 * * \\
(0.000)\end{array}$ & & & $\begin{array}{c}0.772 * * \\
(0.000)\end{array}$ & & & $\begin{array}{c}0.692 * * \\
(0.000)\end{array}$ & & \\
\hline Observations & 121,760 & 46,823 & 74,937 & 83,524 & 29,264 & 54,260 & 116,788 & 44,966 & 71,822 \\
\hline Number of spells & 121,760 & 46,823 & 74,937 & 83,524 & 29,264 & 54,260 & 116,788 & 44,966 & 71,822 \\
\hline Number of failures & 74,294 & 24,691 & 49,603 & 58,670 & 19,362 & 39,308 & 69,322 & 22,834 & 46,488 \\
\hline Log likelihood & $-733,027$ & $-218,596$ & $-466,985$ & $-563,530$ & $-165,221$ & $-361,286$ & $-683,802$ & $-201,781$ & $-437,864$ \\
\hline
\end{tabular}

Notes: The sample and the trade relationships of interest are listed at the top of each column and the covariates are in the first left column. Coefficients are expressed as hazard ratios. P-values are in parentheses. $\quad * *$ and * indicate significance at the $1 \%$ and $5 \%$ level. All regressions include exporter and importer fixed effects, but those coefficient estimates are not reported for brevity. The estimates are stratified by machinery subsectors. Multiple spells of respective exporter-importer-product pairs are treated as independent. Trade data are in constant 2000 U.S. dollars.

${ }^{13}$ Note that the unit in which a variable is measured makes no substantive difference. 
The result for all the observed spells during 1993-2006 is reported in the left part of the table. The estimation for the sample including all machinery products contains a dummy variable which takes a value of one if a trade relationship is of parts \& components. Note that, in this specification, the hazard function of parts \& components is assumed to be proportional to that of finished products, sharing the same baseline hazard. The estimates for all the machinery products confirm the difference in the probability of the survival of trade relationships by product type. Letting trade relationships of finished products be the benchmark, those of parts \& components have a 32\% lower hazard rate. In other words, for parts \& components, once a trade relationship is developed, it is $32 \%$ less likely to be broken off. As for the effects of covariates, a larger distance between exporter and importer countries shifts up the hazard rate by $5.4 \%$ per one thousand kilometers. Although a common border does not have a statistically significant effect on the probability of the survival of trade relationships, a country sharing a common official language with the trade counterpart has a $10 \%$ lower hazard rate than otherwise. In addition, the duration of trade relationships is positively associated with the initial size as well as the prior experience of failure.

One concern is that the baseline hazards might be shaped differently by product type. In the next two columns of the table, the estimation is conducted separately for parts \& components and finished products, using the same covariates. By employing this approach, while we do not care how the product type proportionally shifts a common baseline hazard, we can measure the effects of covariates correctly for each product type. The effects of covariates are similar in direction but different in magnitude by product type. Looking at the estimated coefficients for distance, the hazard rate of finished products increases by $5.9 \%$ due to a larger distance per one thousand kilometers, but for parts \& components, the increase is smaller, at $4.7 \%$. Similarly, the decrease in the hazard rate due to a common language is smaller for parts \& components than finished products. The probability of the survival of trade relationships of parts \& components appear to be less affected by the level of trading cost.

Next, Table 6 provides the Cox hazards estimates, using time-dependent covariates as well as time-invariant variables. In addition, exporter, importer, year fixed effects 
are included to control for unobserved country-specific and year-specific characteristics. $^{14}$

Table 6. Cox Proportional Hazards Estimates for Bilateral Trade Relationships at the Product-line Level: with Time-dependent Covariates

\begin{tabular}{lccc}
\hline & \multicolumn{3}{c}{ All spells } \\
\cline { 2 - 4 } & All machinery & P\&C & FP \\
\hline Distance (1,000km) & $1.084^{* *}$ & $1.082^{* *}$ & $1.085^{* *}$ \\
& $(0.000)$ & $(0.000)$ & $(0.000)$ \\
Border dummy & $0.918^{* *}$ & $0.923^{* *}$ & $0.922^{* *}$ \\
& $(0.000)$ & $(0.008)$ & $(0.000)$ \\
Language dummy & $0.875^{* *}$ & $0.885^{* *}$ & $0.869^{* *}$ \\
& $(0.000)$ & $(0.000)$ & $(0.000)$ \\
Exporter's GDP (100bil US\$) & $0.917^{* *}$ & $0.920^{* *}$ & $0.915^{* *}$ \\
& $(0.000)$ & $(0.000)$ & $(0.000)$ \\
Importer's GDP (100bil US\$) & $0.981^{* *}$ & $0.979^{* *}$ & $0.982^{* *}$ \\
& $(0.000)$ & $(0.000)$ & $(0.000)$ \\
Exporter's credit rating (10 points) & $0.971^{* *}$ & 0.978 & $0.967 * *$ \\
& $(0.000)$ & $(0.093)$ & $(0.001)$ \\
Importer's credit rating (10 points) & $1.031^{* *}$ & $1.032^{*}$ & $1.029^{* *}$ \\
Number of potential suppliers & $(0.000)$ & $(0.015)$ & $(0.001)$ \\
& $0.955^{* *}$ & $0.950^{* *}$ & $0.958^{* *}$ \\
Abs. difference in PCGDP (1,000 US\$) & $(0.000)$ & $(0.000)$ & $(0.000)$ \\
& $0.995^{* *}$ & $0.993^{* *}$ & $0.996^{* *}$ \\
\%change in RER (10\%) & $(0.000)$ & $(0.000)$ & $(0.000)$ \\
& $0.989^{* *}$ & 0.995 & $0.986^{* *}$ \\
Log of initial trade value (US\$) & $(0.003)$ & $(0.424)$ & $(0.003)$ \\
Subsequent spells dummy & $0.878^{* *}$ & $0.851^{* *}$ & $0.890^{* *}$ \\
Frequent breaks dummy & $(0.000)$ & $(0.000)$ & $(0.000)$ \\
P\&C dummy & $0.497^{* *}$ & $0.468^{* *}$ & $0.512^{* *}$ \\
Observations & $(0.000)$ & $(0.000)$ & $(0.000)$ \\
Number of spells & $2.945^{* *}$ & $3.431^{* *}$ & $2.696^{* *}$ \\
Number of failures & $(0.000)$ & $(0.000)$ & $(0.000)$ \\
\hline & $0.803^{* *}$ & & \\
& $(0.000)$ & & \\
\hline & 611,400 & 286,182 & 325,218 \\
& 121,760 & 46,823 & 74,937 \\
& 74,294 & 24,691 & 49,603 \\
\hline & $-721,692$ & $-214,529$ & $-459,975$ \\
\hline
\end{tabular}

Notes: The sample and the trade relationships of interest are listed at the top of each column and the covariates are in the first left column. Coefficients are expressed as hazard ratios. P-values are in parentheses. $\quad{ }^{* *}$ and * indicate significance at the $1 \%$ and $5 \%$ level. All regressions include exporter, importer, and year fixed effects, but those coefficient estimates are not reported for brevity. The estimates are stratified by machinery subsectors. Multiple spells of respective exporter-importer-product pairs are treated as independent. Trade data and GDP data are in constant 2000 U.S. dollars.

${ }^{14}$ The failure's share of the observed trade relationships has hovered around $12 \%$ level; however, the share in 1998 is exceptionally high, at 17\%, due mostly to the Asian crisis, which suggest the need for controlling year-specific effect. 
The result for all the observed spells is reported in the left part of the table again. Even after considering time-dependent aspects, the estimates confirm the difference in the probability of the survival of trade relationships by product type. Trade relationships of parts \& components have a $20 \%$ lower hazard rate with respect to those of finished products. As for the effects of covariates on the hazard rate, most of them are estimated as expected, except that importer country's credit rating is estimated to shift up the hazard rate. Given the development of production networks within the East Asian region, one way to interpret this result is that production shifts, i.e., shifts from exporting to producing a product in a host country, possibly lead to the stop of exports of the product from the home country, as a country with a higher institutional quality would be an attractive investment destination to which foreign corporations relocate production facilities. ${ }^{15}$

Once the model is estimated separately for parts \& components and finished products, again, the effects of covariates are similar in direction but different in magnitude and significance. First and foremost, even after incorporating time-dependent covariates, the risk of discontinuing trade relationships of parts \& components are less likely to be sensitive to the level of trading cost depending on distance, a common language, and a common border. Furthermore, the coefficient for the year-on-year percentage changes in RER is less than one and significant in the finished products equation, but statistically insignificant in the parts equation. Although an appreciation of exporter country's currency increases the hazard rate for finished products, the probability of the survival of trade relationships of parts \& components does not affected by the changes in RER.

\subsection{Robustness Check}

The same Cox model is re-estimated using two different samples so as to examine whether the differences between parts \& components and finished products are robust. As with Section 3.2, one is the sample without 1993-origin spells and the other is the modified sample with the one-year-gap adjustment. As for the specification using only

\footnotetext{
${ }^{15}$ Further investigation into the effect of production shift on the duration of trade relationships is beyond the scope of this paper.
} 
time-invariant variables, the estimates for the two different samples are reported in the middle and right part of Table 5. The patterns of estimated coefficients are similar to the result for all the observed spells, except that the coefficient for the language dummy is statistically insignificant in the parts equation estimated using the sample without 1993-origin spells.

As for the specification using time-dependent as well as time-invariant variables, the estimates for the two different samples are reported in the left part of Table 7. Although the coefficient for RER loses significance at the 5\% level in the finished products equation estimated using the one-year-gap-adjusted sample, the features discussed in the last subsection remain statistically significant. For further reference, the estimates for the first spells sample and the single spells sample are reported in the right part of the table. The result for the first spells shows a similar pattern of estimated coefficients to the result for all the observed spells, whereas the result for single spells differs in some respect. In particular, the coefficient for the border dummy becomes more than one in both the parts and finished products equations, and the magnitude of coefficient for the language dummy is reversed between the equations. These results seem to be due partly to multicolinearity issue. ${ }^{16}$

\footnotetext{
${ }^{16}$ By focusing on single spells, the correlation between the border and the language dummies becomes higher. The correlation between exporter country's GDP and its credit rating also becomes higher for the single spells sample.
} 
Table 7. Robustness Check for the Cox Proportional Hazards Estimates with Time-dependent Covariates

\begin{tabular}{|c|c|c|c|c|c|c|c|c|c|c|c|c|}
\hline & \multicolumn{3}{|c|}{$\begin{array}{c}\text { Without } \\
\text { 1993-origin spells } \\
\end{array}$} & \multicolumn{3}{|c|}{ 1-year-gap-adjusted } & \multicolumn{3}{|c|}{ The first spells only } & \multicolumn{3}{|c|}{ Single spells only } \\
\hline & $\begin{array}{l}\text { All machinery } \\
\text { products }\end{array}$ & $\mathrm{P} \& \mathrm{C}$ & FP & $\begin{array}{c}\text { All machinery } \\
\text { products }\end{array}$ & $\mathrm{P} \& \mathrm{C}$ & FP & $\begin{array}{l}\text { All machinery } \\
\text { products }\end{array}$ & $\mathrm{P} \& \mathrm{C}$ & FP & $\begin{array}{c}\text { All machinery } \\
\text { products }\end{array}$ & $\mathrm{P} \& \mathrm{C}$ & FP \\
\hline Distance & $\begin{array}{c}1.074^{* *} \\
(0.000)\end{array}$ & $\begin{array}{c}1.070^{* *} \\
(0.000)\end{array}$ & $\begin{array}{c}1.076^{* *} \\
(0.000)\end{array}$ & $\begin{array}{c}1.089^{* *} \\
(0.000)\end{array}$ & $\begin{array}{l}1.086^{* *} \\
(0.000)\end{array}$ & $\begin{array}{c}1.090 * * \\
(0.000)\end{array}$ & $\begin{array}{c}1.090^{* *} \\
(0.000)\end{array}$ & $\begin{array}{c}1.084^{* *} \\
(0.000)\end{array}$ & $\begin{array}{c}1.092 * * \\
(0.000)\end{array}$ & $\begin{array}{c}1.168^{* *} \\
(0.000)\end{array}$ & $\begin{array}{c}1.163^{* *} \\
(0.000)\end{array}$ & $\begin{array}{c}1.171^{* *} \\
(0.000)\end{array}$ \\
\hline Border dummy & $\begin{array}{l}0.904^{* *} \\
(0.000)\end{array}$ & $\begin{array}{l}0.911 * * \\
(0.009)\end{array}$ & $\begin{array}{c}0.903^{* *} \\
(0.000)\end{array}$ & $\begin{array}{l}0.915^{* *} \\
(0.000)\end{array}$ & $\begin{array}{l}0.925^{*} \\
(0.014)\end{array}$ & $\begin{array}{c}0.916^{* *} \\
(0.000)\end{array}$ & $\begin{array}{l}0.945^{*} \\
(0.010)\end{array}$ & $\begin{array}{l}0.916^{*} \\
(0.028)\end{array}$ & $\begin{array}{c}0.962 \\
(0.143)\end{array}$ & $\begin{array}{l}1.145^{*} \\
(0.011)\end{array}$ & $\begin{array}{l}1.166 \\
(0.158)\end{array}$ & $\begin{array}{l}1.132 * \\
(0.044)\end{array}$ \\
\hline Language dummy & $\begin{array}{c}0.912 * * \\
(0.000)\end{array}$ & $\begin{array}{c}0.926 * * \\
(0.007)\end{array}$ & $\begin{array}{c}0.901 * * \\
(0.000)\end{array}$ & $\begin{array}{c}0.873 * * \\
(0.000)\end{array}$ & $\begin{array}{c}0.891^{* *} \\
(0.000)\end{array}$ & $\begin{array}{c}0.862 * * \\
(0.000)\end{array}$ & $\begin{array}{c}0.838 * * \\
(0.000)\end{array}$ & $\begin{array}{c}0.861^{* *} \\
(0.000)\end{array}$ & $\begin{array}{c}0.825 * * \\
(0.000)\end{array}$ & $\begin{array}{c}0.834^{* *} \\
(0.000)\end{array}$ & $\begin{array}{l}0.794 * * \\
(0.008)\end{array}$ & $\begin{array}{c}0.827 * * \\
(0.001)\end{array}$ \\
\hline Exporter's GDP & $\begin{array}{c}0.874 * * \\
(0.000)\end{array}$ & $\begin{array}{c}0.874 * * \\
(0.000)\end{array}$ & $\begin{array}{c}0.873 * * \\
(0.000)\end{array}$ & $\begin{array}{c}0.922 * * \\
(0.000)\end{array}$ & $\begin{array}{c}0.926 * * \\
(0.000)\end{array}$ & $\begin{array}{c}0.920 * * \\
(0.000)\end{array}$ & $\begin{array}{c}0.954 * * \\
(0.000)\end{array}$ & $\begin{array}{c}0.950 * * \\
(0.000)\end{array}$ & $\begin{array}{c}0.952 * * \\
(0.000)\end{array}$ & $\begin{array}{c}1.044 * * \\
(0.000)\end{array}$ & $\begin{array}{l}1.110^{* *} \\
(0.000)\end{array}$ & $\begin{array}{l}1.030 * \\
(0.025)\end{array}$ \\
\hline Importer's GDP & $\begin{array}{l}0.955^{* *} \\
(0.000)\end{array}$ & $\begin{array}{l}0.957 * * \\
(0.000)\end{array}$ & $\begin{array}{c}0.954 * * \\
(0.000)\end{array}$ & $\begin{array}{c}0.985^{* *} \\
(0.000)\end{array}$ & $\begin{array}{c}0.984^{* *} \\
(0.005)\end{array}$ & $\begin{array}{c}0.985^{* *} \\
(0.000)\end{array}$ & $\begin{array}{c}0.981^{* *} \\
(0.000)\end{array}$ & $\begin{array}{c}0.972 * * \\
(0.001)\end{array}$ & $\begin{array}{l}0.984 * * \\
(0.009)\end{array}$ & $\begin{array}{c}0.984 \\
(0.064)\end{array}$ & $\begin{array}{c}0.984 \\
(0.351)\end{array}$ & $\begin{array}{l}0.979 * \\
(0.042)\end{array}$ \\
\hline Exporter's credit rating & $\begin{array}{l}0.955 * * \\
(0.000)\end{array}$ & $\begin{array}{l}0.963 * \\
(0.013)\end{array}$ & $\begin{array}{l}0.951 * * \\
(0.000)\end{array}$ & $\begin{array}{c}0.965 * * \\
(0.000)\end{array}$ & $\begin{array}{l}0.973 * \\
(0.044)\end{array}$ & $\begin{array}{c}0.961^{* *} \\
(0.000)\end{array}$ & $\begin{array}{c}0.985 \\
(0.175)\end{array}$ & $\begin{array}{c}0.988 \\
(0.487)\end{array}$ & $\begin{array}{c}0.990 \\
(0.492)\end{array}$ & $\begin{array}{c}0.940 * * \\
(0.009)\end{array}$ & $\begin{array}{c}0.932 \\
(0.118)\end{array}$ & $\begin{array}{c}0.960 \\
(0.147)\end{array}$ \\
\hline Importer's credit rating & $\begin{array}{l}1.019 * \\
(0.037)\end{array}$ & $\begin{array}{l}1.031^{*} \\
(0.044)\end{array}$ & $\begin{array}{l}1.012 \\
(0.285)\end{array}$ & $\begin{array}{c}1.031 * * \\
(0.000)\end{array}$ & $\begin{array}{l}1.032 * \\
(0.018)\end{array}$ & $\begin{array}{c}1.029 * * \\
(0.002)\end{array}$ & $\begin{array}{c}1.042^{* *} \\
(0.000)\end{array}$ & $\begin{array}{c}1.059 * * \\
(0.002)\end{array}$ & $\begin{array}{l}1.033^{*} \\
(0.011)\end{array}$ & $\begin{array}{l}1.037 \\
(0.129)\end{array}$ & $\begin{array}{l}1.106^{*} \\
(0.033)\end{array}$ & $\begin{array}{l}1.007 \\
(0.814)\end{array}$ \\
\hline Number of potential suppliers & $\begin{array}{c}0.959 * * \\
(0.000)\end{array}$ & $\begin{array}{c}0.957 * * \\
(0.000)\end{array}$ & $\begin{array}{c}0.960 * * \\
(0.000)\end{array}$ & $\begin{array}{c}0.951 * * \\
(0.000)\end{array}$ & $\begin{array}{c}0.948 * * \\
(0.000)\end{array}$ & $\begin{array}{c}0.953 * * \\
(0.000)\end{array}$ & $\begin{array}{c}0.950 * * \\
(0.000)\end{array}$ & $\begin{array}{c}0.941^{* *} \\
(0.000)\end{array}$ & $\begin{array}{c}0.956 * * \\
(0.000)\end{array}$ & $\begin{array}{c}0.930 * * \\
(0.000)\end{array}$ & $\begin{array}{c}0.917^{* *} \\
(0.000)\end{array}$ & $\begin{array}{c}0.936 * * \\
(0.000)\end{array}$ \\
\hline Abs. difference in PCGDP & $\begin{array}{c}0.994 * * \\
(0.000)\end{array}$ & $\begin{array}{c}0.993 * * \\
(0.000)\end{array}$ & $\begin{array}{c}0.995^{* *} \\
(0.000)\end{array}$ & $\begin{array}{c}0.994 * * \\
(0.000)\end{array}$ & $\begin{array}{c}0.993 * * \\
(0.000)\end{array}$ & $\begin{array}{c}0.995^{* *} \\
(0.000)\end{array}$ & $\begin{array}{c}0.995^{* *} \\
(0.000)\end{array}$ & $\begin{array}{c}0.992 * * \\
(0.000)\end{array}$ & $\begin{array}{c}0.996 * * \\
(0.000)\end{array}$ & $\begin{array}{c}0.991 * * \\
(0.000)\end{array}$ & $\begin{array}{c}0.986 * * \\
(0.000)\end{array}$ & $\begin{array}{c}0.993 * * \\
(0.000)\end{array}$ \\
\hline \%change in RER & $\begin{array}{c}0.993 \\
(0.087)\end{array}$ & $\begin{array}{l}1.000 \\
(0.951)\end{array}$ & $\begin{array}{l}0.989 * \\
(0.042)\end{array}$ & $\begin{array}{c}0.995 \\
(0.244)\end{array}$ & $\begin{array}{l}1.004 \\
(0.594)\end{array}$ & $\begin{array}{c}0.992 \\
(0.077)\end{array}$ & $\begin{array}{c}0.981^{* *} \\
(0.000)\end{array}$ & $\begin{array}{c}0.990 \\
(0.200)\end{array}$ & $\begin{array}{c}0.976 * * \\
(0.000)\end{array}$ & $\begin{array}{l}1.010 \\
(0.403)\end{array}$ & $\begin{array}{l}1.022 \\
(0.347)\end{array}$ & $\begin{array}{c}1.002 \\
(0.912)\end{array}$ \\
\hline Log of initial trade value & $\begin{array}{c}0.922 * * \\
(0.000)\end{array}$ & $\begin{array}{c}0.911^{* *} \\
(0.000)\end{array}$ & $\begin{array}{c}0.927^{* *} \\
(0.000)\end{array}$ & $\begin{array}{c}0.881 * * \\
(0.000)\end{array}$ & $\begin{array}{c}0.856 * * \\
(0.000)\end{array}$ & $\begin{array}{c}0.893^{* *} \\
(0.000)\end{array}$ & $\begin{array}{c}0.832 * * \\
(0.000)\end{array}$ & $\begin{array}{c}0.795^{* *} \\
(0.000)\end{array}$ & $\begin{array}{c}0.850 * * \\
(0.000)\end{array}$ & $\begin{array}{c}0.862 * * \\
(0.000)\end{array}$ & $\begin{array}{c}0.832 * * \\
(0.000)\end{array}$ & $\begin{array}{c}0.873 * * \\
(0.000)\end{array}$ \\
\hline Subsequent spells dummy & $\begin{array}{c}0.639 * * \\
(0.000)\end{array}$ & $\begin{array}{c}0.573 * * \\
(0.000)\end{array}$ & $\begin{array}{c}0.675^{* *} \\
(0.000)\end{array}$ & $\begin{array}{c}0.565 * * \\
(0.000)\end{array}$ & $\begin{array}{c}0.528 * * \\
(0.000)\end{array}$ & $\begin{array}{c}0.585^{* *} \\
(0.000)\end{array}$ & & & & & & \\
\hline Frequent breaks dummy & $\begin{array}{c}2.080 * * \\
(0.000)\end{array}$ & $\begin{array}{c}2.449 * * \\
(0.000)\end{array}$ & $\begin{array}{c}1.908^{* *} \\
(0.000)\end{array}$ & $\begin{array}{c}3.052 * * \\
(0.000)\end{array}$ & $\begin{array}{c}3.674^{* *} \\
(0.000)\end{array}$ & $\begin{array}{c}2.751^{* *} \\
(0.000)\end{array}$ & & & & & & \\
\hline $\mathrm{P} \& \mathrm{C}$ dummy & $\begin{array}{c}0.847 * * \\
(0.000)\end{array}$ & & & $\begin{array}{c}0.817^{* *} \\
(0.000)\end{array}$ & & & $\begin{array}{c}0.745^{* *} \\
(0.000)\end{array}$ & & & $\begin{array}{c}0.686 * * \\
(0.000)\end{array}$ & & \\
\hline Observations & 233,342 & 95,226 & 138,116 & 616,372 & 288,039 & 328,333 & 455,177 & 225,141 & 230,036 & 369,448 & 195,737 & 173,711 \\
\hline Number of spel & 83,524 & 29,264 & 54,260 & 116,788 & 44,966 & 71,822 & & 27,808 & 39,005 & 34,796 & 16,458 & 18,338 \\
\hline Number of failures & 58,670 & 19,362 & 39,308 & 69,322 & 22,834 & 46,488 & 40,118 & 13,623 & 26,495 & 8,101 & 2,273 & 5,828 \\
\hline Log likelihood & $-557,199$ & $-163,019$ & $-357,176$ & $-672,785$ & $-197,911$ & $-430,971$ & $-366,735$ & $-111,503$ & $-229,419$ & $-64,152$ & $-15,385$ & $-43,775$ \\
\hline
\end{tabular}

Note: $\quad$ See notes of Table 6 


\section{Interpretation}

The survival analyses in the last two sections detect differences in the probability of the survival of trade relationships between parts \& components and finished products in intra-East Asian machinery trade. Parts \& components are traded through longer-lived relationships with respect to finished products. As for the difference in the factors behind the survival of trade relationships by product type, first, the risk of discontinuing trade relationships of parts \& components seems to be less sensitive to the level of trading cost, compared to finished products. Second, the probability of the survival of trade relationships of parts \& components is not affected by the fluctuations in RER, unlike that of finished products.

A higher probability of the survival of parts \& components is thought to be due to the relation-specific nature of the transaction of intermediate goods in international production networks, as discussed in the introductory section. Such relation-specific nature would be not entailed in transactions of finished products made entirely in one country as well as goods sold on the open market. Some may think longer-lived trade relationships of intermediate goods can be interpreted as reflecting that trade of intermediate goods is more driven by intra-firm transactions compared to trade of finished products; however, unfortunately, we cannot obtain detailed trade data classified by type of transaction, i.e., intra-firm or arm's length, as well as by product type. It is more important that, regardless of whether an intermediate good is traded through an intra-firm or arm's length relationship, the transaction of intermediate goods is more likely to be relation-specific, requiring coordination with upstream suppliers and/or downstream buyers across borders.

The insensitivity of parts \& components to the RER fluctuations can be interpreted as a reflection of active back and forth transactions across the region as well as indicating their intrinsic stability. The effect of country's currency appreciation/depreciation on the trade balance appears to be different between trade involving goods of joint production across borders and traditional trade in products made entirely in one country (See Arndt, 2004). If country's imported parts \& components become part of its exports and its exports enter into its imports, the 
exchange-rate effect on the price of exports dominated in one currency might be offset by the exchange-rate effect on the price of imports expressed in the other currency. Cross-border production sharing changes the pass-through of country's currency appreciation/depreciation to its export/import price.

Furthermore, the findings of this paper can be considered in relation to those of a series of studies by Besedeš and Prusa (2006b) and Besedeš (2008) on the duration of the US imports of differentiated products. Besedeš and Prusa (2006b) point out that a longer duration of trade relationships of differentiated products can be explained by relation-specific factors which are intuitively plausible and consistent with many theoretical models. ${ }^{17}$ Given the aforementioned relation-specific nature of the transaction of intermediate goods, although Besedeš (2008) himself finds that intermediate goods face a higher risk of failure than finished products, a longer duration of trade relationships of machinery parts \& components in this paper should be explained by the same token.

\section{Conclusion}

The aim of this paper was to clarify the difference in stability of trade relationships between the transactions of intermediate goods in international production networks and the other transactions. From the perspective of the duration and survival of bilateral trade relationships at the product-line level, the novel empirical approach sheds light on the stability of international production networks in East Asia. Compared to finished products, machinery parts \& components are traded through longer-lived and more stable relationships. Trade relationships of machinery parts \& components have been developed and maintained between countries even at a long distance, regardless of the RER fluctuations. The risk of discontinuing trade relationships of machinery finished products, on the other hand, are more likely to be sensitive to the level of trading cost as well as the RER fluctuations. Although the term "fragmentation" evokes the image of

\footnotetext{
${ }^{17}$ As for the observed short-lived trade relationships, Besedeš and Prusa (2006a) discuss potential explanations including the Ricardian comparative advantage model, the product cycle model as well as the model of trade and search costs.
} 
foot-loose investments, once the production networks are created, trade relationships are rather stable due to the relation-specific nature of transactions.

The probability of the survival of trade relationships is inseparably related to country's trade growth. The firm's ability to maintain the existing trade relationships appears to be crucial to consolidate stable, sustainable export growth. In this context, policy makers would be interested in how to support and facilitate promising firms to maintain ongoing trade relationships. Empirical findings of this paper provide insights into clues to how the probability of the survival of trade relationships can be improved. Given the observed threshold effect for a longer survival, any policy aimed at supporting and facilitating firm's export activities would be particularly important during the early stage of trade relationships when the risk of discontinuance is still high.

In addition to trade liberalization and facilitation policies, the more advanced utilization of FTAs might also accelerate the building and networking of trade relationships across the East Asian region. ${ }^{18}$ In particular, FTAs between Japan/Korea/China and ASEAN appear to have potential for a region-wide development of more stable trade relationships, by facilitating network-forming multinationals to spread fragmented production processes more efficiently across the region. At this stage, as for the impact of Common Effective Preferential Tariff (CEPT) scheme for an ASEAN Free Trade Area (AFTA) on the survival of trade, we found that trade relationships between the AFTA member countries face a $14 \%$ smaller risk of discontinuance with respect to the other trade relationships in and after 2002 though they face a larger risk before 2002. The year 2002 is here treated as a turning point for the progress of trade liberalization among the AFTA member countries; however, as the end year of our sample is 2006, our tentative empirical result is suspected to be due partly to an inevitable right-censoring issue. The impact of the AFTA awaits further study as more years of trade data become available.

As well as maintaining ongoing trade relationships, how to discover a new trading partner and join in international production networks appears to be another crucial issue faced by relatively less developed countries in the East Asian region, and it is ripe for future research.

18 JETRO White Paper 2007 (JETRO 2007: pp. 135-47) presents the present status of utilization of FTAs in the East Asian region (http://www.jetro.go.jp/en/stats/white_paper/). 


\section{Appendix A. Trade Data}

This paper basically uses bilateral import data from the standpoint of reliability, because country of origin is more closely verified due to tariff regulations although final destination may not be known at time of export. Trade data for all the years in the sample are originally reported according to or modified to fit the six-digit level of HS 1992 classification. By using this dataset, although we cannot observe the birth of newly-developed products within a product-line category of the HS 1992 classification, the probability of discontinuing trade relationships will be underestimated, but never be overestimated. More importantly, we do not need to concern about the censoring issue emerging from the complicated mergers and branching of codes due to the update of classification.

I modified data as follows: First, data for the Philippines' imports, which only have been reported according to the HS classification since 1996, are replaced by data for exports to the Philippines. The export data are adjusted by the c.i.f. / f.o.b. ratio specific to the machinery industry sub-sector and exporter-importer pair, which is calculated using the corresponding data reported according to the Standard International Trade Classification (SITC) Rev.3. Second, since the annual data at the HS six-digit level below \$500 (current US\$) are not reported before 2000, trade flows below $\$ 500$ are treated as if there was no trade at all for all the years in the sample.

\section{Appendix B. Data Sources for Other Variables}

\begin{tabular}{ll}
\hline \multicolumn{1}{c}{ Variable } & \multicolumn{1}{c}{ Source } \\
\hline $\begin{array}{l}\text { Distance } \\
\text { Border dummy } \\
\text { Language dummy }\end{array}$ & The CEPII's distance measure database \\
$\begin{array}{l}\text { GDP (constant } 2000 \text { US\$) } \\
\text { Per capita GDP (constant } 2000 \\
\text { US\$) }\end{array}$ & $\begin{array}{l}\text { The World Bank’s World Development Indicators } \\
\text { (WDI) Online }\end{array}$ \\
$\begin{array}{l}\text { Country credit rating } \\
\begin{array}{l}\text { Nominal exchange rate } \\
\text { Wholesale price index }(2000=100) \\
\text { Consumer price index }(2000=100)\end{array}\end{array}$ & The IMF's International Financial Statistics (IFS) \\
\hline
\end{tabular}




\section{References}

Ando, M., Kimura, F., 2005. The formation of international production and distribution networks in East Asia. In: Ito, T., Rose, A. K. (Eds.). International Trade in East Asia. Chicago: University of Chicago Press, 177-213.

Arndt, S. W., 2004. Global production networks and regional integration. In: Plummer M. (Ed.). Empirical Methods in International Trade. Northampton, MA: Edward Elgar, 129-144.

Arndt, S. W., Kierzkowski, H., 2001. Fragmentation: New Production Patterns in the World Economy. Oxford: Oxford University Press.

Athukorala, P.-C., Yamashita, N., 2006. Production fragmentation and trade integration: East Asia in a global context. The North American Journal of Economics and Finance 17, 233-256.

Besedeš, T., 2008. A search cost perspective on formation and duration of trade. Review of International Economics 16, 835-849.

Besedeš, T., Prusa, T. J., 2006a. Ins, outs, and the duration of trade. Canadian Journal of Economics 39, 266-295.

Besedeš, T., Prusa, T. J., 2006b. Product differentiation and duration of US import trade. Journal of International Economics 70, 339-358.

Blyde, J., 2008. What drives export survival? An analysis on export duration in Latin America. Mimeo. Inter-American Development Bank.

Breslow, N., 1974. Covariance analysis of censored survival data. Biometrics 30, 89-100.

Deardorff, A. V., 2001. Fragmentation in simple trade models. North American Journal of Economics and Finance 12, 121-137.

Fukao, K., Ishido, H., Ito, K., 2003. Vertical intra-industry trade and foreign direct investment in East Asia. Journal of the Japanese and International Economies 17, 468-506.

Grossman, G. M., Helpman, E., 2002. Integration versus outsourcing in industry equilibrium. Quarterly Journal of Economics 117, 85-120. 
Grossman, G. M., Helpman, E., 2004. Managerial incentives and the international organization of production. Journal of International Economics 63, 237-262.

Grossman, G. M., Helpman, E., 2005. Outsourcing in a global economy. Review of Economic Studies 72, 135-159.

Jones, R. W., Kierzkowski, H., 1990. The role of services in production and international trade: A theoretical framework. In: Jones, R. W., Krueger, A. O. (Eds.). The Political Economy of International Trade: Essays in Honor of Robert E. Baldwin. Oxford: Basil Blackwell, 31-48.

Kimura, F., 2006. International production and distribution networks in East Asia: Eighteen facts, mechanics, and policy implications. Asian Economic Policy Review 1, 326-344.

Kimura, F., Ando, M., 2005. Two-dimensional fragmentation in East Asia: Conceptual framework and empirics. International Review of Economics and Finance 14, 317-348.

Nitsch, V., 2007. Die another day: Duration in German import trade. CESifo Working Paper No. 2085, CESifo GmbH.

Yeats, A. J., 1995. Are partner-country statistics useful for estimating "missing” trade data? Policy Research Working Paper Series 1501, The World Bank. 


\section{ERIA Discussion Paper Series}

\begin{tabular}{|c|c|c|c|}
\hline No. & Author(s) & Title & Year \\
\hline 2009-03 & Ayako OBASHI & $\begin{array}{l}\text { Stability of Production Networks in East Asia: } \\
\text { Duration and Survival of Trade }\end{array}$ & $\begin{array}{l}\text { Mar } \\
2009\end{array}$ \\
\hline 2009-02 & Fukunari KIMURA & $\begin{array}{l}\text { The Spatial Structure of Production/Distribution } \\
\text { Networks and Its Implication for Technology } \\
\text { Transfers and Spillovers }\end{array}$ & $\begin{array}{l}\text { Mar } \\
2009\end{array}$ \\
\hline 2009-01 & $\begin{array}{l}\text { Fukunari KIMURA } \\
\text { and Ayako OBASHI }\end{array}$ & $\begin{array}{l}\text { International Production Networks: } \\
\text { Comparison between China and ASEAN }\end{array}$ & $\begin{array}{c}\text { Jan } \\
2009\end{array}$ \\
\hline 2008-03 & $\begin{array}{l}\text { Kazunobu } \\
\text { HAYAKAWA and } \\
\text { Fukunari KIMURA }\end{array}$ & $\begin{array}{l}\text { The Effect of Exchange Rate Volatility on } \\
\text { International Trade in East Asia }\end{array}$ & $\begin{array}{c}\text { Dec } \\
2008\end{array}$ \\
\hline 2008-02 & $\begin{array}{l}\text { Satoru KUMAGAI, } \\
\text { Toshitaka GOKAN, } \\
\text { Ikumo ISONO, and } \\
\text { Souknilanh KEOLA }\end{array}$ & $\begin{array}{l}\text { Predicting Long-Term Effects of Infrastructure } \\
\text { Development Projects in Continental South East } \\
\text { Asia: IDE Ceographical Simulation Model }\end{array}$ & $\begin{array}{c}\text { Dec } \\
2008\end{array}$ \\
\hline 2008-01 & $\begin{array}{l}\text { Kazunobu } \\
\text { HAYAKAWA, } \\
\text { Fukunari KIMURA, } \\
\text { and Tomohiro } \\
\text { MACHIKITA }\end{array}$ & Firm-level Analysis of Globalization: & $\begin{array}{l}\text { Dec } \\
2008\end{array}$ \\
\hline
\end{tabular}

